\title{
Brexit vote: absolute numbers are misleading
}

Christopher J Hanretty, reader in politics, Rob Ford, professor of political science

c.hanretty@uea.ac.uk

Dorling writes that "the outcome of the EU referendum has been unfairly blamed on the working class in the north of England ... [but] because of differential turnout and the size of the denominator population, most people who voted Leave lived in the south of England."1

This statement is true but misleading. More people in the south of England voted Leave because there are more people in the south of England.

If we take regions in the north of England to include the north east, north west, and Yorkshire and the Humber, figures from the Electoral Commission show that 4325965 people in the north voted Leave. If we take regions in the south to include the south west, south east, and London, then 5750908 people in the south voted Leave.

However, the electorate in the north was only 11053689 people, compared with 16028306 in the south. Thus, the proportion of registered voters in the north who voted Leave was greater than the proportion in the south $(39.1 \%$ v $35.9 \%)$. And the proportion voting Leave in the north is still greater than in the south if we express it instead in terms of the voting age population.

As political scientists, we are not familiar with the habits of medical journals. In most analyses of voting behaviour it's common to focus on the relative risk of voting for a party or an outcome: an analysis that focuses on absolute numbers is therefore liable to mislead. If medical journals also tend to focus on relative risks then Dorling's analysis is also liable to mislead, notwithstanding qualifications in relation to "differential turnout and the size of the denominator population."

\section{Footnotes}

Competing interests: None declared.

\section{References}

4 Dorling D. Brexit: the decision of a divided country. BMJ2016;354:i3697. doi:10.1136/bmj.i3697 pmid:27383185. 